NBER WORKING PAPER SERIES

\title{
THE INDUSTRIAL ORGANIZATION OF MARKETS WITH TWO-SIDED PLATFORMS
}

\author{
David S. Evans \\ Richard Schmalensee \\ Working Paper 11603 \\ http://www.nber.org/papers/w11603 \\ NATIONAL BUREAU OF ECONOMIC RESEARCH \\ 1050 Massachusetts Avenue \\ Cambridge, MA 02138 \\ September 2005
}

This paper was written as a draft chapter for a forthcoming book, Issues in Competition Law and Policy, edited by W. Dale Collins. The views expressed herein are those of the author(s) and do not necessarily reflect the views of the National Bureau of Economic Research.

(C2005 by David S. Evans and Richard Schmalensee. All rights reserved. Short sections of text, not to exceed two paragraphs, may be quoted without explicit permission provided that full credit, including (C) notice, is given to the source. 
The Industrial Organization of Markets with Two-Sided Platforms

David S. Evans and Richard Schmalensee

NBER Working Paper No. 11603

September 2005

JEL No. D4, L1, L4

\section{ABSTRACT}

Two-sided platforms (2SPs) cater to two or more distinct groups of customers, facilitating value-creating interactions between them. The village market and the village matchmaker were 2SPs; eBay and Match.com are more recent examples. Other examples include payment card systems, magazines, shopping malls, and personal computer operating systems. Building on the seminal work of Rochet and Tirole (2003), a rapidly growing literature has illuminated the economic principles that apply to 2SPs generally. One key result is that 2SPs may find it profit-maximizing to charge prices for one customer group that are below marginal cost or even negative, and such skewed pricing pattern is prevalent, although not universal, in industries that appear to be based on 2SPs. Over the years, courts have also recognized that certain industries, notably payment card systems and newspapers, now understood to be based on 2SPs, are governed by unusual economic relationships. This chapter provides an introduction to the economics of 2SPs and its application to several competition policy issues.

David S. Evans

LECG, LLC

350 Massachusetts Avenue, Suite 300

Cambridge, MA 02139

david_evans@lecg.com

Richard Schmalensee

MIT Sloan School of Management

50 Memorial Drive

Cambridge, MA 02142

and NBER

rschmal@mit.edu 


\section{THE INDUSTRIAL ORGANIZATION OF MARKETS WITH TWO-SIDED PLATFORMS}

\section{INTRODUCTION}

Two-sided platforms (2SPs) cater to two or more distinct groups of customers. Members of one customer group need members of the other group for a variety of reasons that we will explore. The platform helps these customers get together in many ways and thereby creates value for these customers that they could not readily obtain without the coordination provided by the platform. The village market is one of the oldest examples of a 2SP. It is a place where buyers and sellers can get together and trade. So is eBay. Another old example is the village matchmaker who helped help men and women find marriage partners. Match.com provides a similar service using internet technology; speed dating is another important innovation. The publisher of this book operates a platform too. It is in the business of finding authors in search of an audience, and an audience in search of content.

Governments run some 2SPs. Cash is an example. The government institutions behind the Euro help ensure that sellers will take it for payment and buyers will use it for payment; so did the invention of standard metallic coins by the Lydians in the seventh century BC. Standards sometimes give rise to 2SPs. Fax machines facilitate communication between senders and receivers. Cooperatives of firms also operate 2SPs-MasterCard and Visa are the most significant example, as we discuss later.

For-profit businesses operate 2SPs in a wide variety of industries and in many economically significant ones. These have made their founders rich and their current shareholders happy by figuring out how to create value by operating a platform that gets two interdependent customer groups on board. American Express (travelers checks and charge cards), Google (search-engine based portal), and Microsoft (software platforms) are three well-known examples.

William Baxter (1983) presented one of the first formal analyses of a two-sided business. He showed that payment cards provided a service only if both cardholders and merchants jointly agreed to use a card for a transaction. And he demonstrated some of the fundamental economic 
consequences of this joint demand. ${ }^{1}$ However, the notion that diverse industries are based on 2SPs — and are governed by the same economic principles — is due to a seminal paper by JeanCharles Rochet and Jean Tirole (2003). They showed that businesses such as computer operating systems, dating clubs, exchanges, shopping malls, and videogame consoles were based on 2SPs. One of the implications of their work is that 2SPs may find it profitable to charge prices for one side that are below marginal cost or even negative. Empirical work by Evans (2003a, 2003b) documented that this skewed pricing pattern is prevalent, although not universal, in many industries that appear to be based on 2SPs. The study of 2SPs is now a burgeoning field of empirical and theoretical research in economics; notable papers include Armstrong (2002), Armstrong and Wright (2004), and Caillaud and Jullien (2003).

The courts — with the help of economists and lawyers — have also recognized that certain industries, now understood as based on 2SPs are governed by unusual economic relationships. In NaBanco v. Visa USA, the Eleventh Circuit Court of Appeals recognized the key concepts that are still discussed today in the literature on payment card 2SPs. They concluded that the interchange fee-which is paid by the bank that services the merchant to the bank that services the cardholderwas an efficient mechanism for balancing the joint demand by cardholders and merchants for card services. In several newspaper cases the courts have noted that newspapers provide services to two interdependent customer groups_advertisers and readers. For example, the U.S. Supreme Court in Times-Picayune noted, "every newspaper is a dual trader in separate though interdependent markets; it sells the paper's news and advertising content to its readers; in effect that readership is in turn sold to the buyers of advertising space."2

The economics of 2SPs provides a unified framework, informed by theory and crossindustry empirical studies, for considering competition policy issues involving 2SPs. This chapter provides an introduction to this framework and its application to competition policy issues.

Two examples illustrate the relevance of 2SP economics to competition policy. A robust result of the literature is that profit-maximizing prices do not track marginal costs for either group of

\footnotetext{
${ }^{1}$ Important extensions were made to this by Rochet and Tirole (2002), Schmalensee (2002), and Wright (2004).

2 Times-Picayune Pub. Co. v. United States, 345 U.S. 594, 610 (1953). See also, Rysman (2004b) and Oldale and Wang (2004), concerning Yellow Pages as 2SPs.
} 
customers. Contrary to the famous dictum of Areeda and Turner, ${ }^{3}$ a price below marginal cost may be profit maximizing, not predatory. In theory and in fact many 2SPs charge one side a price that does not recover direct costs (video game consoles) and may in fact be negative in the sense that one side is paid to stay on board the platform (shoppers at malls through free parking and other amenities). They therefore earn their profits from a side that typically pays a price well in excess of the direct marginal costs. Competing 2SPs in such an industry could earn a risk-adjusted competitive rate of return even though, under European Community competition law for example, a dominant 2SP could be accused of engaging in a predatory pricing abuse in one "market" and an excessive pricing abuse in another "market." Indeed, as we will see this situation arguably describes the predicament of mobile carriers in Europe.

Another robust result of the literature is that the profit-maximizing prices for 2SPs depends on the price elasticities of demand by customers on both sides, the nature and magnitude of the indirect network effects between the two groups of customers, and marginal costs for both sides. Profit-maximizing prices for the two sides are interlinked. That fact is potentially important for the analysis of market definition and market power both of which hinge, in the case law, on the extent to which firms are constrained to engage in competitive pricing. Although one can debate whether price equals marginal cost is a sensible standard even in single-sided industries, it is clearly not the appropriate standard in two-sided ones.

It is helpful to begin by clarifying a few terms we will use throughout and also note some differences in how these terms are used occasionally in the literature. Many of the scholarly articles by economists refer to "two-sided markets". That term is sometimes applied to businesses that are 2SPs and sometimes to the markets in which they operate. Here we use the term 2SP to refer to the entity - the business, cooperative, standard, or government entity — that provides a physical or virtual platform for distinct customer groups. 2SPs compete in what we will call 2SP industries. Thus dating clubs are platforms that compete in the matchmaking industry. We try to avoid the term two-sided market because the word "market" is a term of art for competition policy. Indeed, one of the issues we will address is how to define market boundaries when the products or services at issue in a competition policy matter are provided by 2SPs.

\footnotetext{
${ }^{3}$ Areeda and Turner conclude "In our analysis of predatory pricing we have concluded that marginal-cost pricing is the economically sound division between acceptable, competitive behavior and 'below-cost' predation. Thus, we have suggested a prohibition of prices below marginal cost.” Areeda and Turner (1975), p. 716.
} 
Although, for the most part, we will use the term two-sided platform the reader should note that some platforms have more than two distinct groups of customers. Software platforms, such as Windows, have at least three: hardware manufacturers, application developers, and end users. 2SPs are a special case of nSPs where $\mathrm{n}>1$. Since most familiar platforms are two-sided we stick with this case to simplify the exposition.

\section{ECONOMIC BACKGROUND ON 2SPS}

A heterosexual singles-oriented club offers some intuition on the economics of 2SPs. A nightclub, such as Bungalo 8 in Manhattan, provides a platform where men and women can meet and search for interactions and potentially dates. The club needs to get two groups of customers on board its platform to have a service to offer either one: it needs to get men and women to come. Moreover, the relative proportion of men and women matters. A singles club with few women will not attract men, and a club with few men will not attract women. Pricing is one way to get the balance right. The club might want to offer women a break if they are in short supply (through a lower price or free drinks). Or it might want to ration the spots to ensure the appropriate number of women; popular clubs typically have queues waiting outside, and attractive women are picked out of line disproportionately.

The dating club is a platform according to the informal definition introduced at the start. There are two groups of customers - men and women. Members of each group value members of the other group. And the platform provides a way for them to get together.

Rochet and Tirole (2004) have proposed a formal definition (note that the word market below is being used in the loose manner that is the custom among economists):

A market is two-sided if the platform can affect the volume of transactions by charging more to one side of the market and reducing the price paid by the other side by an equal amount; in other words, the price structure matters, and platforms must design it so as to bring both sides on board. 
To satisfy this definition, "the relationship between end-users must be fraught with residual externalities" that customers cannot sort out for themselves. ${ }^{4}$ That is clear in the case of the dating environment.

Men and women want to be able to search for dates among a large number of opposites. It is hard to conceive of a practical mechanism for women to reward men who come to a singles club but who they reject. In the other 2SP industries we consider it is difficult if not impossible to imagine customers on one side making side payments to customers on the other side. As a result the platform owner can institute a pricing structure to harness indirect network effects, and it is not feasible for customers to defeat this pricing structure through arbitrage.

It is helpful to distinguish four different types of 2SP: exchanges, advertiser-supported media, transaction devices, and software platforms. ${ }^{5}$ Although this provides a useful classification of 2SPs it is important to note that there is a considerable overlap in the manner in which these 2SPs facilitate interactions among customers groups. While building audiences is central to advertisersupported media, for example, it is important for exchanges as well. To take another example, software platforms eliminate duplicate costs through a shared facility; so do shopping malls and transaction platforms.

\section{EXCHANGES}

Exchanges have two groups of customers who can generally be considered "buyers" and "sellers." The exchange helps buyers and sellers search for feasible contracts—-that is where the buyer and seller could enter into a mutually advantageous trade — and for the best prices—-that is where the buyer is paying as little as possible and the seller receiving as much as possible. (Some securities exchanges, such as the New York Stock Exchange, also need to attract middlemenspecialists or market-makers - who quote prices to both buyers and sellers and bring liquidity to the market.) We use the term buyers and sellers here loosely. It covers various matchmaking activities such as dating services and employment agencies. It also covers traditional exchanges such as auction

\footnotetext{
${ }^{4}$ As a result a necessary condition for a market to be two-sided is that the Coase theorem does not apply to the transaction between the two sides. See Rochet and Tirole (2004) for more details. Generally, one can think of 2SPs as arising in situations in which there are externalities and in which transactions costs, broadly considered, prevent the two sides from solving this externality directly. The platform can be thought of as providing a technology for solving the externality in a way that minimizes transactions costs.

${ }^{5}$ See Hagiu (2004) for discussion. In that paper, we refer to software platforms more generally as shared input facilities. Armstrong (2002) uses the term "competitive bottlenecks" to refer to certain shared-input facilities. Although his discussion is analytically sound, the term is pejorative and has a meaning in competition law that differs from the one he assigns to it.
} 
houses, internet sites for business-to-business, person-to-business, and person-to-person transactions, various kinds of brokers (insurance and real estate) and financial exchanges for bonds and equity. Finally, exchanges include a variety of businesses that provide brokerage services: these include publishers (readers and authors), literary agents (authors and publishers), travel services (travelers and travel-related businesses), and ticket services (people who go to events, and people who sponsor events).

Exchanges provide participants with the ability to search over participants on the other side and the opportunity to consummate matches. Having large numbers of participants on both sides increases the probability that participants will find a match. Depending on the type of exchange, however, a larger number of participants can lead to congestion. That is the case with physical platforms such as singles clubs or trading floors. Moreover, participants may derive some value from having the exchange prescreen participants to increase the likelihood and quality of matches.

Some exchanges charge only one side. For example, only sellers pay directly for the services provided by eBay. It is also true for real-estate sales in the United States: the seller pays. Other exchanges charge both sides, although the prices may bear little relation to side-specific marginal costs. Internet matchmaking services charge everyone the same, for instance, while, as we mentioned, physical dating environs sometimes charge men more than women. Auction houses charge commissions to buyers and sellers. Until the recent settlements in the United States, insurance brokers charged both insurance customers and insurance providers.

\section{ADVERTISING-SUPPORTED MEDIA}

Advertising-supported media such as magazines, newspapers, free television, and web portals are based on a two-sided business model. The platform either creates content (newspapers) or buys content from others (free television). The content is used to attract viewers. The viewers are then used to attract advertisers. There is a clear indirect network effect between advertisers and viewers-advertisers value platforms that have more viewers; the extent to which viewers value 
advertisers is the subject of more debate but we suspect that viewers value advertisers more than they might admit. ${ }^{6}$

Most advertising-supported media earn much of their revenues — and probably all of their gross margins - from advertisers. ${ }^{7}$ Print media are often provided to readers at something close to or below the marginal cost of printing and distribution. ${ }^{8}$ In some cases—such as yellow page directories and some newspapers - they are provided for free. Free-television is just that. And most web portals—Google and Yahoo for example—receive revenue only from advertisers.

\section{TRANSACTION SYSTEMS}

Any method for payment works only if buyers and sellers are willing to use it. Humans switched from barter when they were agreed on a standard metric for exchange- such as metallic coins or seashells. Governments facilitated this by ensuring the integrity of coins (to various degrees) and by using government-issued coinage for buying and selling. Cash, which has no intrinsic value in most modern economies, provides a payment platform because buyers and sellers expect that other buyers and sellers will use it; and of course the government facilitates this with various laws and through its own buying and selling activities.

For-profit transaction systems are based on the same principles although they have challenges that governments — which can create a platform by fiat— do not necessarily have. Although bank checks and travelers' checks are also examples of for-profit transaction systems, we focus on payment cards, which have been the subject of significant competition policy scrutiny in many countries.

\footnotetext{
${ }^{6}$ See, e.g., Ferguson (1983), p.637 ("Readership studies show that advertising, especially retail advertising, is considered as important as, or more important than, editorial content.") and Blair and Romano (1993), p. 731 ("circulation demand rises with increases in the quantity of advertising"). Other studies have shown that, unlike Americans, readers in certain European countries are averse to advertising. See, e.g., Sonnac (2000). On the other hand, TiVo and other related products that permit ad avoidance and deletion are very popular currently, with one study citing that TiVo viewers skip about 60 percent of commercials. See “A Farewell to Ads?” (2004).

${ }^{7}$ In a 2SP there is no rigorous way to define the profit "earned" by one side or the other. Not only are there typically costs that are common to both sides (the floor of the New York Stock Exchange, for instance), outlays that build business on one side of the market (via product enhancement, say) will also tend, via the externality, to build business on the other side. By "gross margin" we mean the difference between revenue and the variable costs that depend entirely on the volume on only one side of the market. The cleanest examples of such a cost would be the manufacturing costs of video game consoles or the marginal printing costs of newspapers or yellow page directories.
}

${ }^{8}$ Blair and Romano (1993). 
Diners Club started the first two-sided payment system in 1950. Before then stores issued payment cards to their customers for use only at their stores. Diners Club began by getting a set of restaurants to agree to take its card for payment; that is to agree to let Diners Club reimburse the restaurant for the meal tab and then in turn collect the money from the cardholder. It also persuaded individuals to take its card and use it for payment. Starting with a small base in Manhattan it grew quickly throughout the United States and other countries.

Diners Club charged restaurants seven percent of the meal tab; cardholders had to pay an annual fee, which was offset in part by the float they received as a result of having to pay their bills only once a month. As a result Diners Club earned most of its revenue-and most likely all of its gross margin - from merchants. Other entrants into the charge and debit card businesses have followed this same approach. Determining who pays in the case of credit cards is a bit more complicated since that product bundles a transaction feature (for which the cardholder pays little) and a borrowing feature (for which the cardholder incurs finance charges). However, it is safe to say that merchants are the main source of earnings for credit cards held by people who do not revolve balances.

American Express, Discover, and, until its recent absorption into MasterCard, Diners Club, set prices to merchants - the merchant discount, which gives rise to a positive variable transaction price - and to cardholders — annual fees and various rewards which may give rise to negative variable transaction prices. Card associations such as MasterCard and Visa are examples of cooperative 2SPs. For a transaction to be consummated there has to be an agreement on the division of profits and the allocation of various risks between the entity that services the merchant and the entity that services the cardholder. Most card associations set this centrally as, in effect, a standard contract between the businesses that service the two sides. Typically, they agree that the entity that services the merchant pays a percent of the transaction — the "interchange fee" - to the entity that services the cardholder. This fee ultimately determines the relative prices for cardholders (issuers obtain a revenue stream which they compete for) and merchants (acquirers pass the cost of the interchange fee onto merchants). This centrally set fee has been the subject of litigation and regulatory scrutiny as we discuss below. ${ }^{9}$

\footnotetext{
${ }^{9}$ Evans and Schmalensee (2005b).
} 


\section{SOFTWARE PLATFORMS}

A software platform provides services for applications developers; these services help developers obtain access to the hardware for the computing device in question as well as other helpful services. Users can run these applications only if they have the same software platform as that relied on by the developers; developers can sell their applications only to users that have the same software platform they have relied on in writing their applications.

Software platforms are central to several important industries. These include personal computers (e.g., Apple, Microsoft); personal digital assistants (e.g., Palm, Treo); 2.5G+ mobile telephones (e.g., Vodafone, DoCoMo), video games (e.g. Sony PlayStation, Xbox); and digital music devices (e.g., Creative Zen Micro, Rio Carbon). With the exception of video games, the software platform owners make most of their revenue, and all of their gross margins, from the user side; developers generally get access to platform services for free, and they obtain various software products that facilitate writing applications at relatively low prices. Video game console manufacturers, on the other hand, typically receive virtually all of their gross margins from licensing access to the software and hardware platforms to game developers; they sell the video game console at close to or below manufacturing cost.

\section{III.ECONOMIC PRINCIPLES}

The theoretical economics literature on 2SPs is relatively new. Economists have derived many results based on stylized models that apply to some of the industries described above. The precise results are sensitive to assumptions about the economic relationships among the various industry participants. Even for these special cases it has turned out to be challenging to derive results without making further assumptions about the precise nature of the demand, cost, and indirect network effects relationships. ${ }^{10}$ Nevertheless, several principles have emerged from this literature that seem to be robust. They appear to depend only on the assumptions that the platform has two groups of customers, that there are indirect network externalities, and that the customers cannot solve these externalities themselves.

10 That is, the models are based on assuming particular functional forms-e.g. linear-for relationships. 


\section{PRICING}

To see the intuition behind pricing consider a platform that serves two customer groups $\boldsymbol{A}$ and $\boldsymbol{B}$. It has already established prices to both groups and is considering changing them. ${ }^{11}$ If it raises the price to members of group $\boldsymbol{A}$ fewer $\boldsymbol{A}$ 's will join. If nothing else changed the relationship between price and the number of $\boldsymbol{A}$ 's would depend on the price elasticity of demand for $\boldsymbol{A}$ 's. Since

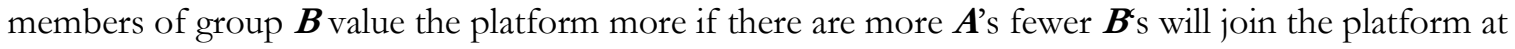
the current price for $\boldsymbol{B}^{\boldsymbol{s}}$ s. That drop-off depends on the indirect network externality which is measured by the value that $\boldsymbol{B}^{\boldsymbol{}}$ s place on $\boldsymbol{A}^{\star}$ s. But with fewer $\boldsymbol{B}^{\star}$ s on the platform, $\boldsymbol{A}^{\star}$ s also value the platform less leading to a further drop in their demand. There is a feedback loop between the two sides. Once this is taken into account the effect of an increase in price on one side is a decrease in demand on the first side because of the direct effect of the price elasticity of demand and on both sides as a result of the indirect effects from the externalities. The change in revenue from a change in price to $\boldsymbol{A}$ therefore depends on the price elasticity of demand for $\boldsymbol{A}$ 's and the indirect network effects between the two sides. (Costs necessarily go down. As is always the case with profit maximization the price increase is profitable if revenues do not decline more than costs decline.)

The platform of course would like to find the prices that maximize its profits by taking these same sorts of considerations into account. For a single-sided business that would occur by selecting the output at which marginal revenue equals marginal cost and then charging the corresponding price for this quantity from the demand curve. (This equilibrium is often described by the standard Lerner formula that says that the price-cost margin equals the inverse of the elasticity of demand.) For 2SPs three results appear to be robust:

1) The optimal prices depend in a complex way on the price elasticities of demand on both sides, the nature and intensity of the indirect network effects between each side, and the marginal costs that result from changing output of each side.

2) The profit-maximizing, non-predatory prices may be below the marginal cost of supply for that side or even negative.

11 To keep matters simple we consider the case where each side is charged a membership fee as in Armstrong (2004). More generally, platforms are natural businesses for two-part tariffs involving an access fee and a usage fee. 
3) An increase in marginal cost on one side does not necessarily result in an increase in price on that side relative to price on the other. ${ }^{12}$ More generally, the relationship between price and cost is complex, and the simple formulas that have been derived by single-sided markets do not apply.

For many platforms it is possible to charge two different kinds of prices: an access charge for joining the platform and a usage charge for using the platform. Although these are interdependent, one can think of the access charge as affecting how many customers join the platform and the usage charge affecting the volume of interactions between members of the platform. Most software platforms charge access charges to users-they have to license the software platform but then can use it as much as they want-and neither access nor usage charges to developers. Videogame console vendors, though, charge a usage fee to game developers — a royalty based on the numbers of games that are sold; users pay this usage fee indirectly through their purchase of games for the console. Payment card systems generally charge merchants a usage fee. Cardholders may pay an access fee (the annual card fee); they pay either no usage fee or a negative one to the extent they receive rewards based on transactions.

The profit-maximizing reliance on access versus usage fees depends on many factors including the difficulty of monitoring usage and the nature of the externality between the two sides. Cardholders care about card acceptance, for instance, while merchants care about usage. It thus seems sensible not to charge merchants for access and not to charge consumers for usage.

The empirical evidence suggests that prices that are at or below marginal cost are common for 2SPs. Table 1 summarizes the evidence.

12 Under the particular demand assumption employed by Rochet and Tirole (2003), the ratio of the profit-maximizing prices charged the two sides is independent of side-specific marginal costs. An increase in the marginal cost on one side will raise both prices, keeping their ratio unchanged. This is not a general result, but it does illustrate a possibility that does not exist in single-sided markets. 
Table 1. Examples of 2SP Pricing Structures

\begin{tabular}{|l|l|cc|}
\hline \multicolumn{1}{|c|}{ Industry } & \multicolumn{1}{|c|}{ Side } & Access & Usage \\
\hline Heterosexual Dating Clubs & Men & $\sqrt{ }$ & $\varnothing$ \\
\hline \multirow{2}{*}{ DoCoMo i-Mode } & Women & $\varnothing$ & $\sqrt{ }$ \\
\hline \multirow{2}{*}{ U.S. Real Estate Brokers } & User & $\sqrt{ }$ & $\varnothing$ \\
\hline \multirow{2}{*}{ Magazines } & Content-Provider & $\varnothing$ & $\varnothing$ \\
\hline \multirow{2}{*}{ Shopping Malls } & Seller & $\sqrt{ }$ & $\varnothing$ \\
\hline PC Operating Systems & Buyer & $\sqrt{(=\mathrm{MC})}$ & $\varnothing$ \\
\hline Video Game Consoles & Reader & $\varnothing$ & $\varnothing$ \\
\hline Payment Card Systems & Advertiser & Shopper & $\sqrt{ }$ \\
\hline & Store & $\sqrt{ }$ & $\varnothing$ \\
\hline
\end{tabular}

Note: $\quad \sqrt{\text { and }} \varnothing$ indicate that the entity either pays or does not pay, respectively, for either access or usage of the 2SP. Items in parentheses indicate where marginal cost or below marginal cost pricing is prevalent for a particular side of a $2 \mathrm{SP}$.

\section{DESIGN DECISIONS}

2SPs are in the business of encouraging customers to join their platforms and stimulating them to interact with each other once they have joined. They design their platforms with this in mind. This can lead to decisions that in a narrow sense harm one side.

A simple example is a shopping mall. Shoppers would prefer to get to stores in the least amount of time. Merchants would like to maximize the amount of foot traffic outside their stores and therefore the number of potential shoppers. Shopping malls are sometimes designed to encourage shoppers to pass by many stores - e.g. by putting the up and down escalators at different ends of the mall.

Advertising-supported media are another obvious example. Viewers would like to gain access to the content—and perhaps even the advertisements of their choice—in the most convenient way. Some magazines are laid out to make it difficult to even find the table of contents or to find the 
continuation of an article without thumbing through many advertisements. Television watchers might benefit from having advertisements clustered at the beginning or the end of each program, but television providers (in the United States, at least) typically intersperse the advertisements and precede them perhaps with a cliffhanger to discourage viewers from taking a long break.

2SPs may also bundle features that directly benefit side $\boldsymbol{A}$ but harm side $\boldsymbol{B}$ (putting aside the indirect externalities from increasing the participation of side $\boldsymbol{A}) \cdot{ }^{13}$ All software platforms include features for example that do not benefit most users. However, some developers value these features and in particular value knowing that any user of the software will have that feature and therefore be able to run its applications. All payment card systems require merchants that take their cards for payment to take any of their cards for payment, regardless of who presents it or which entity issued it. Some merchants would benefit from being selective_-taking cards only from people who lack cash, for example. But this would reduce the security that cardholders have that their cards will be taken at stores that display the acceptance mark. (We will see later that special cases of these requirements, linking acceptances of credit and debit cards, have given rise to tying claims. This paragraph is not meant to suggest that tying could not be used in an anticompetitive way by 2SPs but rather to point out that there is an additional efficiency explanation for at least one aspect of this practice that does not arise in one-sided businesses.)

\section{RULES AND REGULATIONS}

Given that platforms promote interactions between customers and seek to harness indirect network externalities it should come as no surprise that 2SPs have an incentive to devise rules and regulations that promote these externalities and limit negative externalities between customers. The most sophisticated rules and regulations may be those employed by exchanges. All exchanges have rules against "front-running." This practice occurs when a broker receives a large purchase order from a customer, first buys on his own account, then executes the customer order, which drives the price up slightly, and then sells on his own account and pockets the resulting profit. Banning this practice directly harms brokers, but it makes buyers more confident that they are getting the best price possible, and thereby boosts volume on the exchange.

Cooperative 2SPs have further need for rules and regulations because the behavior of their members can affect the value of the 2SP as a whole. Visa, for example, has rules that govern the appearance of cards issued by members, to provide some uniformity for the common brand, as well

13 See Rochet and Tirole (2004). 
as to prevent members from using the brand inappropriately. The system also has rules that address disputed transactions. Acquirers would have an incentive to favor their customers (merchants) in a dispute while issuers would favor their customers (cardholders). The system's rules attempt to find a balance between these competing interests, to increase the attractiveness of the system as a whole.

\section{INDUSTRIAL ORGANIZATION OF MARKETS WITH 2SPS}

Casual empiricism shows that industries with 2SPs are quite diverse. We explain some of the basic determinants of this heterogeneity form a theoretical perspective and then document aspects of it by surveying industries that appear to be dominated by 2SPs.

\section{DETERMINANTS OF PLATFORM SIZE AND STRUCTURE}

Five fundamental factors determine the relative size of competing 2SPs. Table 2 summarizes the factors we discuss below and their effect on size (with a "+" indicating that there is a positive association between size and the factor).

Table 2. Determinants of Industry Structure

\section{Cause}

Indirect network effects

Scale economies

Congestion

Multi-homing

Platform differentiation

\section{Effect on Size/Concentration}

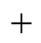

$+$

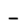

\section{INDIRECT NETWORK EFFECTS}

Indirect network effects between the two sides promotes larger and fewer competing 2SPS.

Platforms with more customers of each group are more valuable to the other group. For example, more users make software platforms more valuable to developers and more developers make software platforms more valuable to users. These positive-feedback effects make platforms with more customers on both sides more valuable to these customers. To take another example, a 
payment card systems whose cards are taken at more merchants is more valuable to card users- that is why we see card systems touting their acceptance ("MasterCard: No card is more accepted.") in consumer advertisements.

If there were no countervailing factors, we would expect that indirect network effects would lead 2SPs to compete for the market. First movers would have an advantage, all else being equal. We would have the familiar story that the firm that obtains a lead tends to widen that lead as a result of positive-feedback effects and therefore wins the race for the market. ${ }^{14}$ Other firms could compete with this advantage only if they offered consumers on either side something that offset the first mover's size advantage.

Indirect network effects may decline with the size of the platform. For example, the probability of finding a match increases at a diminishing rate with the number of individuals on either side (buyers or sellers, men or women). ${ }^{15}$ At some point positive externalities from more participants may turn into negative externalities in the form of congestion as discussed below.

\section{ECONOMIES AND DISECONOMIES OF SCALE}

For many 2SPs there would appear to be significant fixed costs of providing the platform. This should lead to scale economies over some range of output. For example, card payment systems have to maintain networks for authorizing and settling transactions for cardholders and merchants (and for their proxies - issuers and acquirers - in the case of association-based payment systems such as MasterCard). The costs of developing, establishing, and maintaining these networks are somewhat independent of volume. To take another example, there is a fixed cost of developing a software platform but a low marginal cost of providing that platform to developers and end users. In some cases the scale economies may mainly operate on one side. For example, there are scale economies in providing newspapers to readers (there is a high fixed cost of creating the newspaper and a relatively low marginal cost of reproducing and distributing it) but not in providing space to advertisers. Lastly, some physical platforms such as trading floors and singles clubs have scale economies at least in the short run, up to their capacity levels.

\footnotetext{
${ }^{14}$ See, e.g., Evans and Schmalensee (1996) and Shapiro and Varian (1999).

${ }^{15}$ Evans (2003a), p. 377.
} 
Diseconomies may set in at some point for various reasons on one or both sides. For example, to persuade existing end users to replace (i.e. upgrade) their existing software platforms software, platform vendors have to add features and functionality. Many of these improvements may be designed to encourage application developers to write new or improved applications for the platform that in turn benefit end users. However, as software platforms have gotten larger and more complex, it has become more expensive and time consuming to add features and functionality. The most recent version of the Apple OS took four months longer to develop than the previous version. ${ }^{16}$ Microsoft's forthcoming Longhorn operating system has also been plagued with delays.

\section{CONGESTION AND SEARCH OPTIMIZATION}

Several design issues tend to limit the size of 2SPs. Physical platforms such as trading floors, singles clubs, auction houses, and shopping malls help customers search for and consummate mutually advantageous exchanges. At a given size expanding the number of customers on the platform can result in congestion that increases search and transaction costs. ${ }^{17}$ It may be possible to reduce congestion by increasing the size of the physical platform, but that in turn may increase search costs. Indeed, to optimize search for partners, 2SPs may find that it is best to limit the size of the platform and prescreen the customers on both sides to increase the probability of a match. One might argue that singles-type clubs do this explicitly (deciding who can get into an "exclusive" club) or implicitly (compare church-oriented singles groups and Club Med resorts). We will return to this subject below in discussing platform differentiation. Congestion may arise on one side alone. For example, increasing the volume of advertising in a newspaper may not only crowd out the content that attracts the readers but also result in a cacophony of messages that reduces the effectiveness of any particular advertisement.

\section{PRODUCT DIFFERENTIATION AND MULTIHOMING}

Because two-sided platforms are subject to network effects and tend to have scale economies one might expect that industries based on 2SPs would tend towards natural monopoly or at least be highly concentrated. Product differentiation is an important countervailing force.

${ }^{16}$ For Apple OS release dates, see Snell (2002), Stokely (2003), and Musil (2005). 
Platforms can differentiate themselves from each other by choosing particular levels of quality (what is known as "vertical differentiation") with consumers choosing the higher or lower quality of platform depending on the income and relative demand for quality. There are, for example, upscale and downscale malls. Platforms can also differentiate themselves from each other by choosing particular features and prices that appeal to particular groups of customers (what is known as "horizontal differentiation"). Thus there are numerous advertising-supported magazines that appeal to particular segments of readers and advertisers (e.g. Cape Cod Bride or Fly Fisherman).

Horizontal differentiation can result in customers choosing to join and use several platforms - a phenomenon that Rochet and Tirole have called "multi-homing". Customers find certain features of different competing platforms attractive and therefore rely on several. Payment cards are an example of multi-homing on both sides. Most merchants accept credit and debit cards from several systems including ones that have relatively small shares of cardholders. Many cardholders carry multiple credit cards, although they may tend to use a favorite card most often. ${ }^{18}$ Advertising-supported media also have multi-homing on both sides-advertisers and viewers rely on many differentiated platforms. Other 2SPs have multi-homing only on one side. Most end-users rely on a single software platform for their personal computers, for instance, while many developers write for several platforms.

\section{EMPIRICAL EVIDENCE ON 2SP INDUSTRY STRUCTURE}

While there has been little rigorous empirical study of 2SPs, it is possible to see some regularities across industries in which 2SPs appear to be the dominant form of organization. Table 1 above and Table 3 reveal several features:

- Except for some exchanges and software platforms, it is relatively uncommon for industries based on 2SPs to be monopolies or near monopolies. Some industries based on 2SPs have several large differentiated platforms, while others have many small platforms that are differentiated by location as well as along other dimensions.

- Multihoming on at least one side is common, indicating that horizontal product differentiation tends to be the norm.

- Asymmetric pricing is relatively common. Many 2SPs appear to obtain the preponderance of their operating profits (revenues minus direct costs) from one

\footnotetext{
${ }^{17}$ For a general discussion on matching, search, and congestion see, for example, Shimer and Smith (2001) and Rysman (2004b).

18 Rysman (2004a).
} 
side. A nontrivial portion of 2SPs appear to charge prices that are below marginal cost or below zero. 
Table 3. Presence of Multihoming and Largest Competitor Share of Selected 2SPs

\begin{tabular}{|c|c|c|c|}
\hline $\begin{array}{l}\text { Multi-Sided } \\
\text { Platform }\end{array}$ & Sides & Presence of Multihoming & $\begin{array}{l}\text { Largest Competitor Share } \\
\text { in the United States }\end{array}$ \\
\hline $\begin{array}{l}\text { Residential Property } \\
\text { Brokerage }\end{array}$ & $\begin{array}{l}\text { Buyer } \\
\text { Seller }\end{array}$ & $\begin{array}{l}\text { Uncommon: Multihoming may be unnecessary, } \\
\text { since a multiple listing service allows the listed } \\
\text { property to be seen by all member agencies' } \\
\text { customers and agents. }\end{array}$ & $\begin{array}{l}\text { Fifty largest firms have a } \\
23 \% \text { share. }(2002)\end{array}$ \\
\hline $\begin{array}{l}\text { Securities } \\
\text { Brokerage }\end{array}$ & $\begin{array}{l}\text { Buyer } \\
\text { Seller }\end{array}$ & $\begin{array}{l}\text { Common: The average securities brokerage } \\
\text { client has accounts at three firms. Note that } \\
\text { clients can be either buyers or sellers or both. }\end{array}$ & $\begin{array}{l}\text { Four largest firms accounted } \\
\text { for } 37 \% \text { of in securities } \\
\text { brokerage and } 16 \% \text { in } \\
\text { financial portfolio } \\
\text { management. }(2002)\end{array}$ \\
\hline $\begin{array}{l}\text { Newspapers and } \\
\text { Magazines }\end{array}$ & $\begin{array}{l}\text { Reader } \\
\text { Advertiser }\end{array}$ & $\begin{array}{l}\text { Common: In 1996, the average number of } \\
\text { magazine issues read per person per month } \\
\text { was 12.3. Also common for advertisers: for } \\
\text { example, AT\&T Wireless advertised in the } \\
\text { New York Times, The Wall Street Journal, } \\
\text { and Chicago Tribune, among many other } \\
\text { newspapers, on Aug. 26, } 2003 \text {. }\end{array}$ & $\begin{array}{l}\text { Wall Street Journal had a } \\
28 \% \text { share of the five largest } \\
\text { newspapers. (2001) }\end{array}$ \\
\hline Network Television & $\begin{array}{l}\text { Viewer } \\
\text { Advertiser }\end{array}$ & $\begin{array}{l}\text { Common: For example, viewers in Boston, } \\
\text { Chicago, Los Angeles, and Houston, among } \\
\text { other major metropolitan areas, have access to } \\
\text { at least four main network television channels: } \\
\text { ABC, CBS, FOX, and NBC. Also common for } \\
\text { advertisers: for example, Sprint places television } \\
\text { advertisements on ABC, CBS, FOX, and } \\
\text { NBC. }\end{array}$ & $\begin{array}{l}\text { U.S. law forbids broadcasters } \\
\text { from owning TV stations } \\
\text { reaching more than } 35 \% \text { of } \\
\text { the nation's television } \\
\text { audience. }\end{array}$ \\
\hline Operating System & $\begin{array}{l}\text { End User } \\
\text { Application } \\
\text { Developer }\end{array}$ & $\begin{array}{l}\text { Uncommon for users: Individuals typically use } \\
\text { only one operating system. Common for } \\
\text { developers: As noted earlier, the number of } \\
\text { developers that develop for various operating } \\
\text { systems indicates that developers engage in } \\
\text { significant multihoming. }\end{array}$ & $\begin{array}{l}\text { Microsoft has a } 96 \% \text { share } \\
\text { of revenue of client } \\
\text { operating systems. (2004) }\end{array}$ \\
\hline $\begin{array}{l}\text { Video Game } \\
\text { Console }\end{array}$ & $\begin{array}{l}\text { Game Player } \\
\text { Game } \\
\text { Developer }\end{array}$ & $\begin{array}{l}\text { Varies for players: The average household (that } \\
\text { owns at least one console) owns } 1.4 \text { consoles. } \\
\text { Common for developers: For example, in } 2003 \text {, } \\
\text { Electronic Arts, a game developer, developed } \\
\text { for the Nintendo, Microsoft, and Sony } \\
\text { platforms. }\end{array}$ & $\begin{array}{l}\text { Sony PS1 and PS } 2 \text { had a } \\
63 \% \text { share of console } \\
\text { shipments in North } \\
\text { America. (2003) }\end{array}$ \\
\hline Payment Card & $\begin{array}{l}\text { Cardholder } \\
\text { Merchant }\end{array}$ & $\begin{array}{l}\text { Common: Most American Express cardholders } \\
\text { also carry at least one Visa or MasterCard. In } \\
\text { addition, American Express cardholders can } \\
\text { use Visa and MasterCard at almost all places } \\
\text { that take American Express. }\end{array}$ & $\begin{array}{l}\text { The Visa system had a } 45 \% \\
\text { share of all credit, charge, } \\
\text { and debit purchase volume. } \\
\text { (2004) }\end{array}$ \\
\hline
\end{tabular}

Source: Adapted from Evans (2003a). Industry share data from United States Census Bureau, 2002 Economic Census <http://www.census.gov/econ/census02/guide/INDSUMM.HTM>; "Top 20 U.S. Daily Newspapers by Circulation," Newspaper Association of America <http://www.naa.org/info/facts01/18_top20circ/index.html>; Stephen Labaton, "U.S. Backs Off Rules for Big Media," New York Times, January 28, 2005; Al Gillen and Dan Kusnetzky, "Worldwide Client and Server Operating Environments 2004-2008 Forecast," IDC Market Analysis, No. 32452, December 2004; Schelley Olhava, "Worldwide Videogame Hardware and Software 2004-2008 Forecast and Analysis," IDC Market Analysis, No. 31260, May 2004; The Nilson Report, No. 828, February 2005; The Nilson Report, No. 833, May 2005. 


\section{OVERVIEW OF ANTITRUST CASES INVOLVING 2-SIDED MARKETS}

Many antitrust cases have involved 2SPs. A few-including several important ones-seem to have touched on two-sided issues before economists began to address them formally. And some are based on analyses of markets and practices that, putting aside whether they led to the correct verdict of or not, are analytically wrong from the perspective of the recent 2SP literature.

Table 4. Summary of Leading Cases by 2SP Type

\begin{tabular}{|c|c|c|}
\hline & Case & Case Type \\
\hline \multirow{4}{*}{ 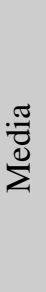 } & Times Picayune & Monopolization \\
\hline & Magill & Refusal to supply \\
\hline & BT Yellow Pages & Monopolization \\
\hline & Lorain Journal & Exclusive dealing \\
\hline \multirow{4}{*}{ 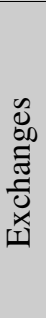 } & $\begin{array}{l}\text { Sotheby's- } \\
\text { Christies }\end{array}$ & Cartel \\
\hline & Marsh McLennan & Cartel \\
\hline & $\begin{array}{l}\text { London Stock } \\
\text { Exchange }\end{array}$ & Merger \\
\hline & Mobile operators & Excessive Pricing \\
\hline
\end{tabular}

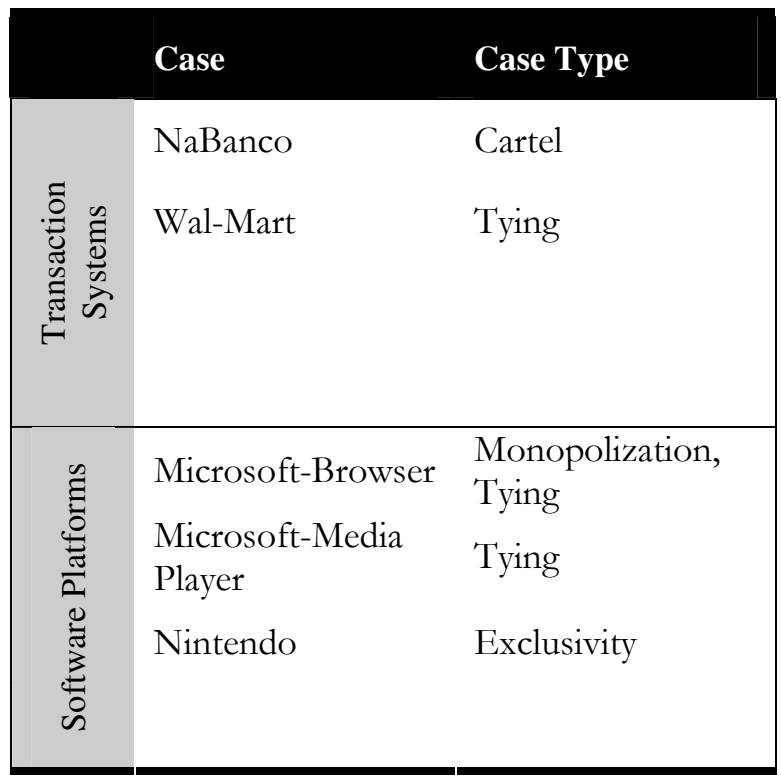

Table 4 presents an overview of antitrust cases in the European Community and the United States that concern 2SPs. We have not done a systematic review of cases but have rather listed cases that have had a high profile in these jurisdictions and with which we are generally familiar. The cases span all of the major categories of 2SPs and involve the spectrum of competition policy issues. This section summarizes the issues that arose in some of these cases.

\section{NABANCO}

NaBanco v. Visa is unique among the cases we consider. The federal district court and the Eleventh Circuit Court of Appeals recognized several of the key features of what have become known as 2SPs. Visa was (and is) a cooperative of banks that issued cards and acquired those card transactions from merchants. It established a rule for governing the situation in which an individual whose card was issued by bank A paid with that card at a merchant acquired by bank B, where A and 
$\mathrm{B}$ are different banks. Although those banks could have a bilateral agreement, Visa established a default rule that among other things determined the allocation of the profits and risks of the transaction. This rule provided that given the various allocations of risks and costs that the bank that acquired the transaction (B) had to pay the bank (A) that issued the card a percent of the transaction amount; this percent is known as the interchange fee, and it was initially set at 1.95 percent.

$\mathrm{NaBanco}$ argued that the interchange fee violated Section 1 of the Sherman Act because it was a price set collectively by competitors. Visa argued that unlike classic price fixing, the ability to set an interchange fee was a mechanism to allocate costs between the issuing and acquiring sides of the business and enhanced output by, among other things, limiting opportunistic behavior by individual members and avoiding the chaos of bilateral negotiations among thousands of member banks. The Eleventh Circuit concluded:

Another justification for evaluating the [interchange fee] under the rule of reason is because it is a potentially efficiency creating agreement among members of a joint enterprise. There are two possible sources of revenue in the VIS A system: the cardholders and the merchants. As a practical matter, the card-issuing and merchant-signing members have a mutually dependent relationship. If the revenue produced by the cardholders is insufficient to cover the card-issuers' costs, the service will be cut back or eliminated. The result would be a decline in card use and a concomitant reduction in merchant-signing banks' revenues. In short, the cardholder cannot use his card unless the merchant accepts it and the merchant cannot accept the card unless the cardholder uses one. Hence, the [interchange fee] accompanies "the coordination of other productive or distributive efforts of the parties" that is "capable of increasing the integration's efficiency and no broader than required for that purpose." $"$

Professor William Baxter worked for Visa on this matter. His 1983 article in the Journal of Law and Economics presented many of the key concepts of two-sided markets within the context of the determination of interchange fees. The modern literature now recognizes that the interchange fee is at least partly a device for determining the pricing structure for the card system..$^{20}$ Some regulators and antitrust authorities, while recognizing the two-sided nature of the business, have argued in

\footnotetext{
${ }^{19}$ National Bancard Corp. v. Visa U.S.A., Inc., 779 F.2d 592, 602 (11 th Cir. 1986).

20 See, e.g., Schmalensee (2002), Rochet and Tirole (2002 and 2003), Wright (2004), and Evans and Schmalensee (2005a and 2005b).
} 
recent years that the interchange fee is set at a level that encourages the overuse of cards. They have argued for some form of cost-based regulation, even though it seems generally accepted by economists that, unlike the public-utility case, there is no basis for assuming that cost-based pricing will lead to the socially optimal pricing structure or even an improvement over the profit-maximizing structure. $^{21}$

\section{LONDON STOCK EXCHANGE}

In December 2004, Euronext and Deutsche Börse, respectively the second and third largest stock exchanges in Europe by value of trading, made bids to take over the London Stock Exchange, the largest stock exchange in Europe. Both bids were referred to the UK's Competition Commission for investigation under UK competition law-they did not qualify for investigation by the European Commission under EU law. The Competition Commission is due to report in September 2005.

Stock exchanges exhibit a number of different network effects. First, indirect network effects exist between (a) issuers of stocks and shares (generally governments and companies) whose shares are traded on the exchange and (b) the investors who trade in those shares. Both groups value the presence of the others and stock exchanges are therefore 2SPs. Second, network effects exist between investors, since the larger the number of investors using an exchange the more liquid will be the market and the more attractive it is to trade there. Third, network effects exist between traders in post-trade services such as the clearing and settlement of trades (the process by which ownership of shares is transferred form sellers to buyers). A trader will benefit from lower costs if it uses the same clearing and settlement system as the traders with whom it buys and sells shares.

Traditionally, stock exchanges have tended to be local monopolies, due in large part to regulations that restricted cross-border trading. Although these restrictions have been relaxed, exchanges have tended to maintain their positions as national monopolists, due in part to the impact of the various network effects described above. There has been very little direct competition between the London Stock Exchange and other European exchanges, such as Euronext and Deutsche Börse, for example. One key question which the Competition Commission is examining is whether these network effects will continue to limit the scope for competition between exchanges or

${ }^{21}$ Evans and Schmalensee (2005b). 
whether competition between these exchanges could in the future occur, perhaps involving the market "tipping" from one exchange to another.

\section{MICROSOFT MEDIA PLAYER}

The European Commission found that Microsoft had abused a dominant position in operating systems by including media player technologies in Windows. ${ }^{22}$ It argued that there were indirect network effects between the use of media players and the provision of content. If more people have a particular media player, content providers will tend to encode content in that format. If more content is available in the format for a particular media player, users will tend to use that media player. The Commission argued that content providers would standardize on Windows Media Player as a result of the fact that this player was available on most personal computers, which of course included Windows. In effect, the Commission argued that the existence of network effects would result in the "media player market" tipping to Windows Media Player. ${ }^{23}$

For its part Microsoft has agreed that there are indirect network effects but that the existence of such effects are not sufficient to tip a market to a single platform. In particular, it has argued that media players are horizontally differentiated products and that most content providers and many users engage in multihoming. Who is right on this score depends on factual disputes between the Commission and Microsoft that we do not consider here.

\section{MAGILL}

The Magill case is a leading European Community case involving the compulsory licensing of intellectual property. What makes it interesting from a two-sided standpoint is that it involved several interlinked 2SPs. The defendants in the case were three television stations (RTE, BBC, and ITV) whose broadcasts were received in Ireland. RTE and ITV were 2SPs, receiving revenues from advertisers. RTE was also supported by licenses paid by consumers for having television sets. The $\mathrm{BBC}$ received similar revenues from licenses for television sets in the UK (but not Ireland). The BBC did not allow advertising and was not a 2SP. All three stations published an advertising-supported television guide that contained their own weekly listings; these were 2SPs. In addition they each provided their daily listings to newspapers — other 2SPs — that combined the listings.

\footnotetext{
${ }^{22}$ For contrary views on this case, see Dolmans and Graf (2004). See also, Evans and Padilla (2004).

${ }^{23}$ Order of the President of the Court of First Instance (2004), $9 \uparrow \mid 365,388$.
} 
Magill TV Guide (Magill) wanted to publish a weekly advertising-supported guide that contained the listings of the three stations. The stations complained that this violated their copyrights. The Commission and ultimately the European courts concluded that there would be a market - in the antitrust sense-for a weekly television guide and that the refusal to supply the copyrighted information prevented the emergence of the weekly guide product. As it turns out, the weekly newspapers were the main beneficiaries of this decision since they started weekly television supplements included in the Sunday newspapers. Magill never made a successful go of it.

We will return to this case when we discuss the analysis of market definition and market power. The key point is that the analysis by all the parties (including the television stations) ignores a key side of the 2SP industry here-the advertisers who were the likely source of much of the revenue and profits—as well as the link between the guides and the television business.

\section{MARSH AND MCLENNAN}

Marsh and McLennan is an insurance broker. It assists companies in securing insurance coverage from insurance companies in addition to advising these companies on risk management type issues. The New York State Attorney's General office complained that Marsh represented to companies that it was securing a competitive price for the insurance but that, in fact, it was charging the insurance companies a commission for the brokerage service and rigging the bids from insurance companies to make it appear to the insurance buyer that it was getting a fair price. Marsh and McLennan entered into a settlement in which it agreed to put aside $\$ 850$ million dollars to reimburse its insurance buying clients.

The fact that a broker charges both sides of the market is not inconsistent with what one might expect in a two-sided business. Many brokers in fact have asymmetric prices in which only the buy side or the sell side is charged. For example, residential real estate brokers in the United States only collect from the seller. Some 2SP exchanges, however, do charge both sides. For example, Sotheby's and Christies both openly charged commissions to buyers and sellers (they were accused of price fixing to the sellers, and possibly the buyers $\left.{ }^{24}\right)$.

In the case of Marsh and McLennan, the fact that it is a 2SP business is relevant for addressing some of the issues. There is no reason why charging prices on both sides is

\footnotetext{
${ }^{24}$ See, e.g., Frantz et al. (2000).
} 
anticompetitive. Charging prices on both sides only yields supra-competitive profits if the insurance brokerage market were not sufficiently competitive or if there were collusive agreements with the other brokers. Otherwise, the insurance brokers would compete the commissions (including the unreported commissions to insurance companies) down and thereby eliminate this source of profits. But, perhaps most importantly, the 2SP literature is most helpful for emphasizing that the ultimate issue in this case was not the fact that both sides were charged but rather the alleged attempt to hide the existence of sell-side commissions and the manipulation of the bids being presented to the buyside.

\section{ANTITRUST IMPLICATIONS OF TWO-SIDED PLATFORM ECONOMICS}

Whether the economics of 2SPs can assist in determining whether a merger or business practice is anticompetitive is, like many aspects of economics, an empirical question. As with market power generally two-sidedness is a matter of degree. Sometimes the two-sided nature of the business is critical for the analysis. Other times it is an interesting aspect of the industry that should be thought about but is not ultimately determinative. Still other times an industry may have two-sided aspects that are too insubstantial to matter.

\section{MARKET DEFINITION AND MARKET POWER}

It is useful to start with market power to clarify ideas. We generally care about determining whether an entity (a firm or a collection of firms) has market power for three reasons that vary in importance across antitrust matters. First, entities that have or could obtain significant market power can by definition raise prices above the competitive level, restrict output, and reduce consumer and social welfare. Second, and related, entities that have significant market power generally have the ability and incentive to engage in business practices that could foreclose competition. Third, entities that obtain significant market power as a result of a business practice may be able to recoup costs they incur from investing in anticompetitive activities such as predatory pricing and vertical foreclosure. Business practices engaged in by entities that either lack market power or are unlikely to acquire it are often presumed benign (except of course for naked price fixing and related cartel practices).

The economics of 2SPs provides several insights into analysis of market power.

1) The link between the customers on the two-sides limits the extent to which a price increase on either side is profitable. It therefore necessarily limits market power, all else equal. Consider two sides $\boldsymbol{A}$ and $\boldsymbol{B}$. An increase in the price to side $\boldsymbol{A}$ reduces 
the number of customers on side $\boldsymbol{A}$ and therefore reduces the value that customers on side $\boldsymbol{B}$ receive from the platform. That in turn reduces the price that side $\boldsymbol{B}$ will pay and the number of customers on side $\boldsymbol{B}$. The reduction in the number of customers on side $\boldsymbol{B}$ in turn reduces the price that customers on side $\boldsymbol{B}$ will pay and reduces their demand. These positive feedback effects may take some time to work themselves out, but it is clear that the ordinary price elasticity on side A understates true price sensitivity.

2) Competition on both sides limits profits. Suppose in a market without multi-homing that there is limited competition on side $\boldsymbol{A}$ because customers cannot easily switch between vendors of that side, but there is intense competition on side $\boldsymbol{B}$ because customers can and do switch between vendors based on price and quality. Then if competitors on side $\boldsymbol{B}$ cannot differentiate their products and otherwise compete on an equal footing, the ability to increase prices on side $\boldsymbol{A}$ will not lead to an increase in profits. Any additional profits on side $\boldsymbol{A}$ will be competed away on side $\boldsymbol{B}$. This point is especially relevant for assessing incentives and recoupment. It is also worth noting that the possibility of multi-homing on side B will permit positive profits, since it reduces the intensity of competition.

3) Price equals marginal cost (or average variable cost) on a particular side is not a relevant economic benchmark for 2SPs for evaluating either market power or claims of predatory pricing. As we saw above, the price on each side is a complex function of the elasticities of demand on both sides, indirect network effects, and marginal costs on both sides. Thus it is incorrect to conclude, as a matter of economics, that deviations between price and marginal cost on one side provide any indication of pricing to exploit market power or to drive out competition. ${ }^{25}$

The constraints on market power that result from interlinked demand also affect market definition. Market definition assists in understanding constraints on business behavior and assessing the contours of competition that are relevant for evaluating a practice. In some cases, the fact that a business can be thought of as a 2SP may be irrelevant. That could happen either because the indirect network effects though present are small or because nothing in the analysis of the practices really hinges on the interlinked demand. In other cases, the fact that a business is a $2 \mathrm{SP}$ will prove important both by identifying the real dimensions of competition and focusing on sources of constraints. ${ }^{26}$

\footnotetext{
${ }^{25}$ For the 2SP as a whole, a formula similar to the standard Lerner index emerges in the Rochet-Tirole model. This is not a general result, and it thus suggests that the overall price-cost margin is somewhat less relevant than in single-sided businesses for evaluating overall market power.

${ }^{26}$ See Evans and Noel (2005).
} 


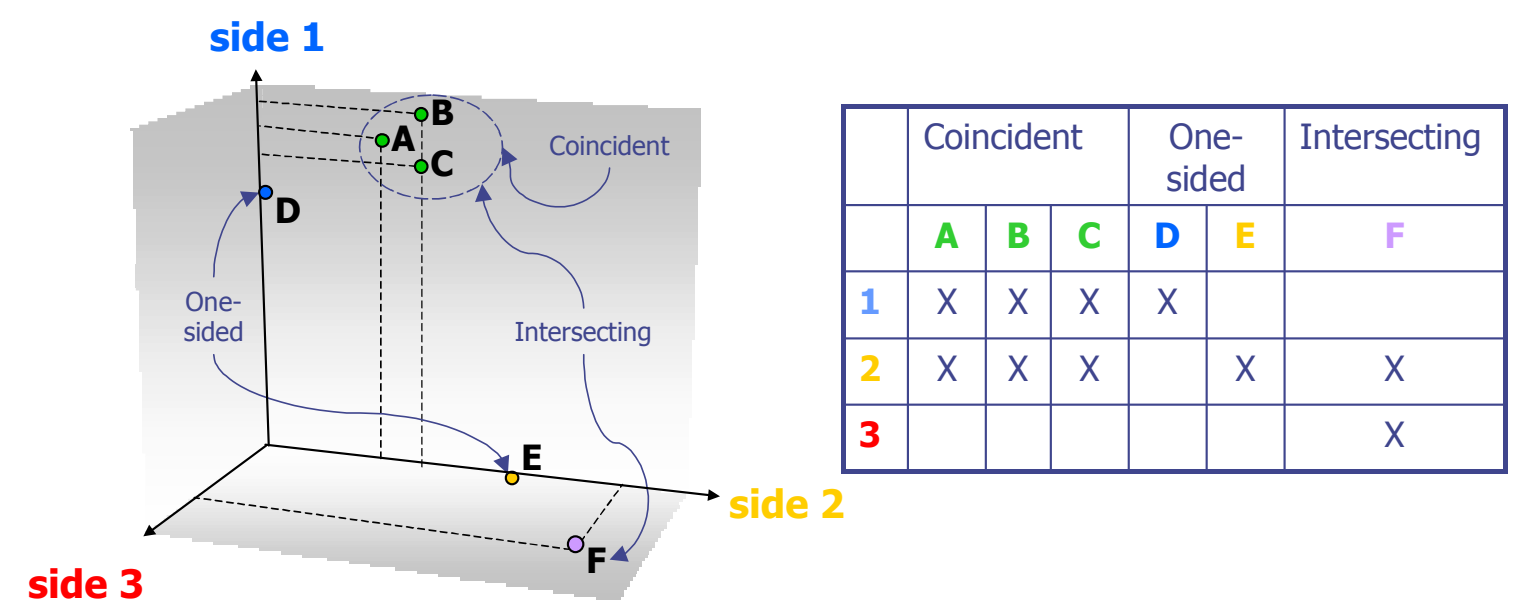

Figure 1. Types of Differentiated Platform Competition

Figure 1 shows potential sources of competition constraints for a two-sided platform denoted by $\boldsymbol{A}$. It faces competition of some degree from other differentiated 2SPs that serve the same customer groups (e.g. the newspapers in a city). It also faces competition from single-sided businesses that provide competitive services to one side only (e.g. billboards). And it faces competition from other 2SPs that provide a product that competes mainly with one side but not the other (e.g., advertising-supported television). Again, the existence of these constraints does not mean they are important, only that they need to be looked at.

\section{COORDINATED PRACTICES}

The key insight of the economics of 2SPs in the oligopoly context is that to be successful cartels may need to coordinate on both sides. Consider the situation in which there are several competing 2SPs. If they agree to fix prices on one side only the cartel members will tend to compete the supracompetitive profits away on the other side. This observation has two corollaries. The first is that it is harder to form an effective cartel in an industry with 2SPs than in single-sided industries, all else equal. The cartel requires more agreements and monitoring because of the additional side. The second is that if an authority finds evidence of a price fix on one side it should probably look carefully for evidence on the other side. This was relevant, as we note above, in the price fixing case involving Sotheby's and Christie's. 
The economics of 2SPs is also relevant for evaluating the practices of cooperatives and joint ventures as we saw from the discussion of the $\mathrm{NaBanco}$ case. Payment card systems, financial exchanges, and music collecting societies are examples of 2SPs that are organized as cooperatives. The 2SPs adopt various rules and regulations for the members and take charge of certain centralized functions. The economics of 2SPs is useful for assessing whether there is an efficiency rationale behind an agreement over prices. In NaBanco, as we noted, the court found that the collective setting of the interchange fee helped balance the demands between cardholders and merchants (in 2SP terms it helped internalize an externality) and eliminated the need for bilateral negotiations (in 2SP terms it reduced the transactions cost of internalizing the externality).

\section{UNILATERAL PRACTICES}

In trying to assess whether unilateral practices are anticompetitive the economic features of 2SPs need to be considered.

\section{PREDATORY AND EXCESSIVE PRICING}

Our review of pricing showed that a robust conclusion of the economics literature is that profit-maximizing 2SPs may find that it is profitable overall to price the product offered on one side below average variable cost, below marginal cost, or even below zero. Casual empiricism and reports from 2SPs indicates that such below-cost pricing is common, occurs in stable market equilibrium, and is therefore not designed mainly for the purpose of foreclosing competition. Therefore, there is no presumption that below-cost pricing is anticompetitive. Of course, it is certainly possible for a 2SP to engage in predatory pricing by setting its price on one side so low as to deny other platforms access to this side of the market. It is also possible for a 2SP to engage in 2-sided predatory pricing, charging below cost overall on both sides with the purpose of foreclosing competitors. Cost-based tests make some sense in the latter case, but it is hard to see how they could be used to analyze an allegation of one-sided predation.

Under Article 82 of the EC Treaty a dominant firm can be found to have made an abuse by charging an "unfair purchase or selling prices." Just as a below-cost price on one side can emerge in long-run market equilibrium so can an above-cost price on the other side. Indeed, such belowcost/above-cost prices will come together. This issue has come up in a series of cases in Europe in which regulator authorities have found mobile telephone operators to have charged fixed-line carriers "excessive" prices for terminating calls on their networks; the authorities recognize that the profits 
from these excessive prices are competed away in part through low prices for handsets and call origination. Indeed, UK's Office of Communication (OfCom) recognized that mobile telephone platforms were highly competitive (on the mobile subscriber side at least) and did not overall earn supracompetitive returns. ${ }^{27}$ Although they did not accept that this was a two-sided business, and did not apply that analysis, OfCom did provide an "indirect network externality" kicker to the regulated price it imposed on the mobile termination side. ${ }^{28}$

\section{TYING}

Under a rule of reason analysis ${ }^{29}$ the economics of 2SP can provide an explanation for certain tying practices that seem to reduce consumer choice and harm consumers. As we discussed above, the platform provider designs the platform - including the constellation of services and features - to harness internalized externalities, minimize transactions costs between the customers and both sides, and maximize the overall value of the platform. As part of internalizing externalities this platform provider wants to increase positive indirect network effects while limiting negative indirect network effects. As a consequence, the 2SP may impose requirements on side $\boldsymbol{A}$ that do not benefit them directly and which customers on that side might even reject after comparing private benefits and costs. But such requirements may benefit side $\boldsymbol{B}$. And if the demand increases on side $\boldsymbol{B}$ these requirements may increase the value placed on the platform on side $\boldsymbol{A}$ —and in fact could increase value so much that the feature provides a net benefit to side $\boldsymbol{A} .{ }^{30}$

The honor-all-cards rule for payment cards is a possible example. Card systems generally require that merchants that agree to take the system's branded cards agree to take all branded cards that are presented by shoppers. Thus, merchants that have a contract to take American Express cards cannot decide to take payment by Amex corporate cards but not Amex personal cards, or to take payment from visibly wealthy travelers but not from locals. For at least some merchants the private

\footnotetext{
${ }^{27}$ See, e.g., Office of Telecommunications (2003), \$1.2 ("no mobile network operator, either individually or in combination with one or more other mobile network operators, has [significant market power] in that market."). No provider has a share exceeding 28 percent. See, e.g., "United Kingdom: Telecoms and Technology Background" (2004).

28 OfCom Statement (2004), pp. 163-172; Armstrong (2002), p. 14.

${ }^{29}$ Economists and legal scholars generally agree that tying should be considered under a rule of reason analysis rather than a per se test. That is not the state of the law in the United States or the European Community both of whose highest courts have adopted something closer to a per se test of liability. However, both courts admit that efficiencies can at least play a limited role in the analysis (in the United States through the separate product test and in the European Union through the possibility of "objective justification" of the practice).

${ }^{30}$ See Rochet and Tirole (2004).
} 
benefit of this requirement outweighs its cost (generally we would expect that merchants would privately want a choice to take whatever card they wanted). However, this rule makes the system's branded card more valuable to its cardholders, who have the assurance that their card will be accepted for payment at merchants that display the system's acceptance mark. By increasing the number of cardholders it makes the card a more valuable payment device for merchants to accept. ${ }^{31}$

\section{EXCLUSIVE DEALING}

The potential for profits on the other side provides a possible incentive for exclusive contracts in 2SPs. One of the main Chicago School observations about exclusive contracts is that a consumer is always free not to agree to exclusivity. The conclusion is that exclusivity in contracts must reflect consumers' judgment that the benefits (lower prices or efficiencies) outweigh the costs of only dealing with one firm. In 2SPs, it is at least possible that there is an externality; exclusive contracts on one side might help a platform gain market power on other sides. The consumers agreeing to the exclusive contracts on one side might, at least in the short run, gain from or be indifferent to exclusivity, but they may not take into account the costs to consumers on the other sides from decreased platform competition. Some recent work suggests that it is at least theoretically possible for a 2SP to use exclusive contracts to exclude competitors, although the welfare consequences of these contracts are ambiguous. ${ }^{32}$

As with exclusivity in one-sided markets, however, this can only be a concern if one firm has exclusivity over most or all of the market and if the exclusivity is persistent and durable. For example, consumers on the nonexclusive side could respond by moving to a competing platform, thus exerting pressure on consumers on the exclusive side to end exclusivity. Moreover, in markets with significant buyer concentration, the buyers would be reluctant to agree to exclusivity if there is some expectation that it will lead to dominance by that platform, as that will likely result in higher prices in the future for all sides. As with one-sided markets, one needs to consider whether the efficiencies from

\footnotetext{
31 A class of merchants claimed that Visa and MasterCard had illegally tied by requiring merchants that accepted their credit cards to also accept their debit cards. The card associations agreed to end this practice after a federal district court judge applied the per se tying test and ruled that the associates failed several prongs of this test as a matter of law. In re Visa Check/MasterMoney Antitrust Litigation, 192 F.R.D. 68 (E.D.N.Y 2000). American Express has been sued by a class of merchants for illegally tying its corporate and personal cards. See Kuykendall (2005).

32 See Armstrong and Wright (2004).
} 
exclusive contracts - for example, in helping to create a platform that might not otherwise exist for the benefit of consumers - offset possible costs from reducing competition.

\section{QUALIFICATIONS AND CONCLUSIONS}

The indirect network effects between customer groups served by a single business are strong in many important industries. Businesses in these industries operate 2SPs. The economics of 2SPs provides insights into how these businesses and industries behave that are relevant for competition analysis including market definition, coordinated practices, and unilateral practices. The economic literature provides robust results - that is, ones that are not dependent on only fragile assumptionsthat can assist in this analysis. These results include the consequences of interlinked demand between customer sides for prices; prices do not, contrary to the standard model, have a tight relationship with cost.

As with almost any application of economics to policy several cautions are prudent. First, many of the theoretical results in the literature to date are, like those in other areas of industrial organization, based on quite abstract models of how industries operate and special assumptions of demand and cost. Second, to date there has been little rigorous empirical research on 2SPs or competition among them. Third, the theoretical and empirical work to date suggests that how 2SP businesses work is highly dependent on the specific institutions and technologies of an industry. One must be careful generalizing. 


\section{REFERENCES}

“A Farewell to Ads?” 2004. Economist, April 15.

Armstrong, Mark. 2002. “Competition in Two-Sided Markets,” Working Paper, August (Revised May 2005).

Armstrong, Mark, and Wright, Julian. 2004. "Two-Sided Markets, Competitive Bottlenecks and Exclusive Contracts," Working Paper, November.

Areeda, Phillip, and Donald F. Turner. 1975. "Predatory Pricing and Related Practices Under Section 2 of the Sherman Act.," Harvard Law Review, vol. 88, pp. 697-733.

Baxter, William F. 1983. "Bank Exchange of Transactional Paper: Legal and Economic Perspectives," Journal of Law and Economics, vol. 26, no. 3 (October), pp. 541-588.

Blair, R.D., and Romano, R.E. 1993. "Pricing Decisions of the Newspaper Monopolist," Southern Economic Journal vol. 59, pp. 721-732

Caillaud, Bernard, and Jullien, Bruno. "Chicken \& Egg: Competition among Intermediation Service Providers," Rand Journal of Economics, vol. 34, no. 2 (Summer), pp. 309-328.

Dolmans, Maurits and Thomas Graf. 2004. “Analysis of Tying Under Article 82 EC: The European Commission's Microsoft Decision in Perspective," World Competition, vol. 27, no. 2, pp. 225244.

Evans, David S. 2003a. “The Antitrust Economics of Multi-Sided Platform Markets," Yale Journal on Regulation, vol. 20, no. 2 (Summer), pp. 325-381.

. 2003b. "Some Empirical Aspects of Multi-Sided Platform Industries," Review of Network Economics, vol. 2, issue 3 (September), 191-209.

, and Michael Noel. 2005. Defining Antitrust Markets When Firms Operate Multi-Sided Platforms," Columbia Business Law Review, forthcoming. , and A. Jorge Padilla. 2004. "Tying Under Article 82 EC and the Microsoft Decision: A Comment on Dolmans and Graf," World Competition, vol. 27, no. 4, pp. 503-512. 
and Richard Schmalensee. 1996. "A Guide to the Antitrust Economics of Networks," Antitrust Magazine, vol. 10, no. 2 (Spring), pp. 36-40. , and , 2005a. Paying with Plastic: The Digital Revolution in Buying and Borrowing, 2nd Ed., Cambridge, Massachusetts: MIT Press. , and , 2005b. "The Economics of Interchange Fees and Their Regulation: An Overview," Working Paper, May. (presented in "Interchange Fees in Credit and Debit Card Industries: What Role for Public Authorities?” an international Payments Policy conference sponsored by the Federal Reserve Bank of Kansas City) , Andrei Hagiu, and Richard Schmalensee. 2004. "A Survey of the Economic Role of Software Platforms in Computer-Based Industries," October (forthcoming in Industrial Organization and the Digital Economy Illing, G. and M. Peitz, eds. (MIT Press))

Ferguson, James M. “Daily Newspaper Advertising Rates, Local Media Cross-Ownership, Newspaper Chains, and Media Competition," Journal of Law and Economics, vol. 26 (October), pp. 635-654.

Frantz, Douglas Ralph Blumenthal, and Carol Vogel. 2000. "Ex-Leaders of 2 Auction Giants Are Said to Initiate Price-Fixing," New York Times, April 7.

Hagiu, Andrei. 2004. "Platforms, Pricing, Commitment and Variety in Two-Sided Markets," Princeton University Doctoral Dissertation, June.

Kuykendall, Lavonne. 2005. "Merchants Suing Amex Add Citi, MBNA as Defendants," American Banker, vol. 170, no. 12 (January 19).

Musil, Steven. 2005. “This Week in Tiger: Apple releases Mac OS X 10.4,” CNet News, April 29.

Office of Telecommunications (OfTel). 2003. "Discontinuing Regulation: Mobile Access and Call Origination Market," November 4, available online http://ofcom.org.uk/static/archive/oftel/publications/eu_directives/2003/discon1103.pdf.

Oldale, Allison, and Elizabeth Wang. 2004. “A Little Knowledge Can Be A Dangerous Thing: Price Controls in the Yellow Pages Industry," European Competition Law Review, vol. 25, no. 10 (October) pp. 607-610. 
"Order of the President of the Court of First Instance. (Proceedings for Interim Relief-Article 82 EC).” 2004. Case T-201/04 R 2, Microsoft Corporation v. Commission, December 22, available online, http://curia.eu.int/en/content/juris/index form.htm.

Rochet, Jean-Charles, and Jean Tirole. 2002. "Cooperation among Competitors: Some Economics of Credit Card Associations," Rand Journal of Economics, vol. 33, no. 4 (Winter), pp. 549-570. , and — 2003. "Platform Competition in Two-Sided Markets," Journal of the European Economics Association, vol. 1, no. 4 (June), pp. 990-1209. , and ,2004. "Tying in Two-Sided Markets and the Impact of the Honor All Cards Rule," Working Paper, March.

Rysman, Mark. 2004a. “An Empirical Analysis of Payment Card Usage,” Working Paper, May. . 2004b. "Competition Between Networks: A Study of the Market for Yellow Pages," Review of Economics Studies, vol. 71, pp. 483-512.

Schmalensee, Richard. 2002. "Payment Systems and Interchange Fees," Journal of Industrial Economics, vol. 50, no. 2 (June), pp. 103-122.

Shapiro, Carl, and Hal R. Varian, Information Rules: A Strategic Guide to the Network Economy, Boston, Massachusetts: Harvard Business School Press.

Shimer, Robert and Smith, Lones. 2001. "Matching, Search, and Heterogeneity," Advances in Macroeconomics, vol. 1, no. 1.

Snell, Jason. 2002. “Jaguar unleashed: Mac OS X 10.2 Arrives,” Macworld, September 1.

Sonnac, Nathalie. 2000. “Readers' Attitudes Toward Press Advertising: Are They Ad-Lovers or AdAverse?" Journal of Media Economics, vol. 13, no. 4, pp. 249-259.

Stokely, Sarah. 2003. “Apple Sets Panther Release Date,” IDG Data, October 10.

"United Kingdom: Telecoms and Technology Background." 2005. Economist Intelligence Unit, November 1.“Wholesale Mobile Voice Call Termination.” 2004. Office of Communication 
(OfCom) Statement, June 1, available online, http://www.ofcom.org.uk/consult/condocs/mobile_call_termination/wmvct/wmvct.pdf.

Wright, Julian. 2004. "One-Sided Logic in Two-Sided Markets," Review of Network Economics, vol. 3, no. 1 (March), pp. 44-64. 